\title{
The Impact of the COVID-19 Pandemic on Greek Tourism-Updates and Comparisons
}

\begin{abstract}
By Gregory T. Papanikos*
This paper updates and compares the results obtained in Papanikos' (2020a) paper published in the Athens Journal of Tourism, which estimated the impact of the current pandemic on international Greek tourism receipts and tourist arrivals. The COVID-19 pandemic continues to have negative effects on Greek tourism and the Greek economy. In this paper, newly released data by the Bank of Greece for the entire 2021 period are used to assess the impact on Greek tourism during the two pandemic years of 2020 and 2021. In addition, the actual data from 2020 are compared with the estimates of the three scenarios made in the 2020 paper. One conclusion that emerges from the analysis of the data on international tourism is that in 2021 Greek tourism did much better than in 2020, but still is far away from the record year of 2019. In 2021, international tourist arrivals and international tourism receipts accounted for $48 \%$ and $58 \%$ of the 2019 values respectively.
\end{abstract}

Keywords: pandemic, COVID-19, crisis, tourism, Greece, economic impact

\section{Introduction}

COVID-19 has hit all countries in the world showing the dark side of globalization where it matters most, i.e., in the loss of human lives. Only world wars could be considered worse. The global academic community responded immediately by doing research on the various aspects of the virus, producing quite a large number of studies, which at the early stages of the spread of the virus created a number of controversies between nations and international organizations such as the World Health Organization (WHO). It seems that these animosities have by now subsided and a global consensus has almost emerged, albeit there exist some people who hold heterodoxy views on how to deal with COVID-19. The number of studies has mushroomed and spread around the world faster than the virus itself. For example, the Athens Institute for Education and Research (ATINER) has published, or is about to publish, close to 50 studies on the various aspects of COVID-19- so many that a survey of these studies will be published as a collection in a book to be edited by Boutsioli et al. (2022) (see also Jones \& Comfort [2020]). In a series of books, I have examined many aspects of the Greek tourism and hospitality industries (Papanikos, 2000, 2001, 2002, 2005). A comparison of the pandemic which hit Athens in 430 BCE with the current one is examined in Papanikos (2020b). Finally, the recent recovery plan of the European Union to deal with COVID-19 is discussed in Papanikos (2021).

*President, Athens Institute for Education and Research (ATINER), Greece; Honorary Professor of Economics, University of Stirling, UK; and Professor, MLC Ljubljana, Slovenia. 
Undoubtedly the most important impact of COVID-19 after the loss in human lives is the negative shock on the economies around the world. The pandemic shattered the world economies because these are so much integrated than never before in world history. The development of transportation technology brought more and more people together which fuelled the spread of the virus. The solution of social distancing and even personal isolation meant that people could not travel, not only internationally, but nationally in different areas within their own national boundaries. For example, in Greece not only was international travel restricted or banned altogether, but moving from one area (prefecture) to another area within Greece was also not allowed. As a result of such harsh measures, unparalleled for peace years, tourism was gravely affected. As a consequence, total output was felt most dramatically. In the case of Greece, this could not have come to a worse time after the Great Recession of 2008, which also hit the Greek economy at an unprecedented rate for a non-war period.

In 2020, I published a paper in this journal where I developed three scenarios of the possible impacts of COVID-19 on Greek tourism, and therefore on the total economy. For that study, I used whatever information was available at the time of February 2020. Therefore, I could not have taken into consideration the complete lockdown of the Greek tourism market for international and national traveling that occurred during the second quarter of 2020. In this current study, I compare my estimates based on the three possible scenarios at the time with the actual performance of the international Greek tourism receipts and arrivals in 2020.

Including this introductory section, this study is organized into five sections. The second section compares the Greek GDP trajectory in the $21^{\text {st }}$ century which includes positive and negative shocks. On the positive side, during this period of two decades, Greece became a founding member of the eurozone and successfully organized the Olympic Games of 2004. Even though there are scholars who argue that both events have had a negative effect on Greek economy, the performance of the Greek Gross Domestic Product (GDP) does not vindicate them as I show in the next section. However, by the end of the first decade and by the beginning of the third decade of the $21^{\text {st }}$ century, Greece's economy was badly hit by the Great Recession of 2008 and the pandemic of 2020-2021 respectively. These effects can now be evaluated using the GDP oscillations during the entire period. The third section compares my early estimates of the three scenarios on the impact of pandemic in 2020 with the actual performance of the international Greek tourism using quarterly data of tourism receipts. The fourth section uses monthly data of international travel receipts and arrivals to demonstrate the effect of the pandemic. The last section concludes.

\section{The Greek GDP in the $21^{\text {st }}$ Century}

Figure 1 shows total real GDP in the $21^{\text {st }}$ century (2000-2023). The last two years are the forecast estimates of the European Commission. As far as the Greek economy is concerned, the $21^{\text {st }}$ century is characterized by four developments, two 
of which were predicted and planned because they were the deliberate choices of Greek government authorities.

First, in 2002 Greece became one of the initial members of the eurozone. In Papanikos (2022a), I have evaluated the first two decades of Greece's membership to the eurozone and I concluded that: "Despite the dismal picture painted and the uncertainty surrounding the introduction of the euro, the Greek economy did better in the two decades of the euro, relative to the two decades preceding the introduction of the euro" (Papanikos 2022a, p. 188).

This is obvious if one looks at Figure 1; GDP increased from 2000 up to 2010, but it dropped drastically in the second decade. Nevertheless, the decrease in the GDP even though very deep, was still higher than any other value of the entire $20^{\text {th }}$ century (not shown in the graph). This aspect has been discussed in detail in Papanikos (2014).

Figure 1. Greek GDP, 2000-2023

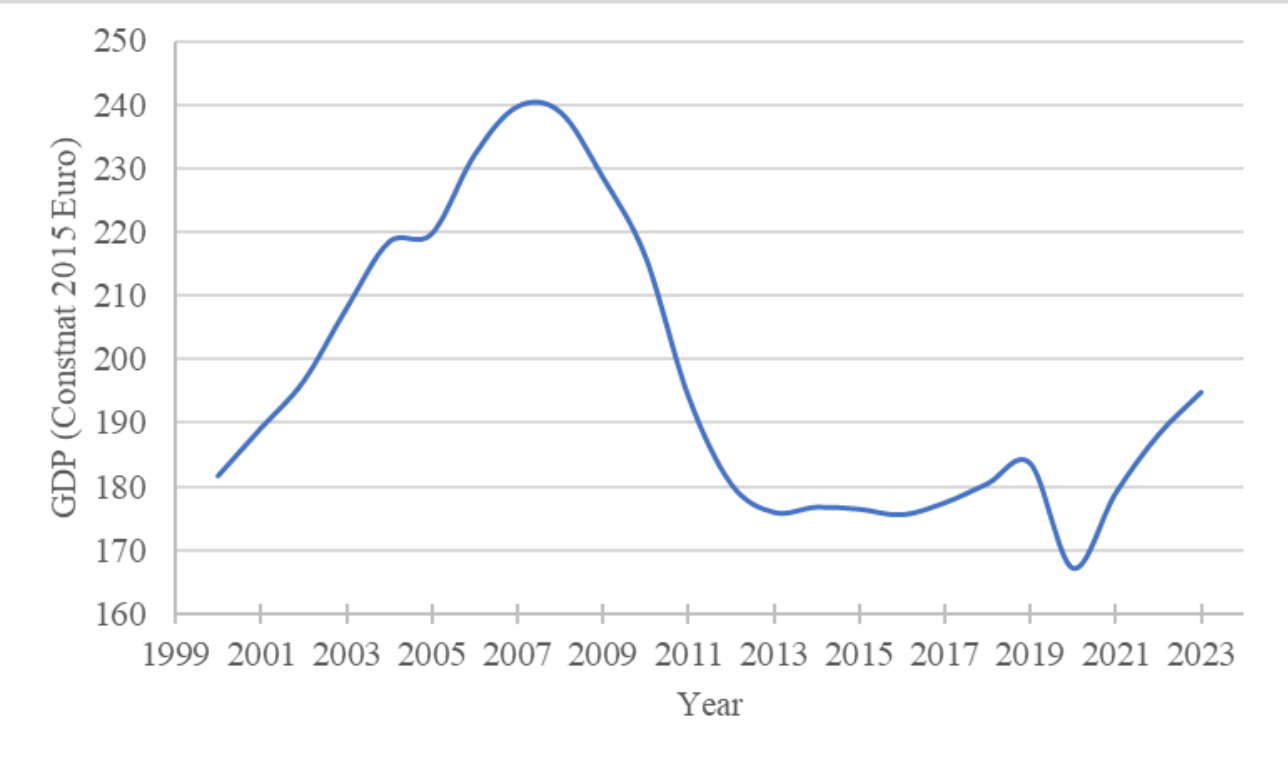

Source: Eurostat (AMECO database).

The second significant development was the organization of the Olympic Games in 2004. An ex-ante evaluation of the economic and tourism effects of the Olympic Games was presented in Papanikos (1999) and recently these effects were evaluated ex post in Papanikos (2022b). Even though I claimed that the Olympic effect was positive, I stated that this conclusion should be interpreted with caution because of the Great Recession of 2008.

The Great Recession was the third development of the $21^{\text {st }}$ century, which has had a negative effect on the Greek economy. It hit Greece's economy very hard, but, as explained in Papanikos (2015), this was also the result of an overvalued euro. Never before in its history had the Greek economy had to cope with such a hard currency as was the case of the euro in the first decade of its circulation. 
The fourth development is the current pandemic of which its effects on the economic and tourism sectors are evaluated in this paper. By examining Figure 1 and Table 1, the conclusion which emerges is that the pandemic had a detrimental effect on Greek GDP, but it was not worse than the impact of the Great Recession of 2008. The last column of Table 1 reports the output loss relative to the previous year.

In 2007, the Greek economy achieved its highest-ever value of GDP of 239.7 billion of constant 2015 euro. From 2000 to 2008, the rate of growth of GDP was positive, reaching its highest rate just the year before the Olympic Games. In 2003 the rate of growth of GDP was $5.8 \%$, primarily because of the huge government spending in public works to prepare Athens and Greece for the Olympic Games of 2004. The strong performance continued into 2004 with 5.05\% growth. In 2005, there was only a meagre economic growth of $0.6 \%$, but it jumped to $5.64 \%$ in 2006, which is the second highest rate after 2003 of the first two decades of the $21^{\text {st }}$ century.

Table 1. Greek GDP: Total, Growth and Change (bn of 2015 euro)

\begin{tabular}{|c|c|c|c|}
\hline Year & GDP & \%GDP & D(GDP) \\
\hline 2000 & 181.6 & 3.95 & 6.9 \\
\hline 2001 & 189.1 & 4.13 & 7.5 \\
\hline 2002 & 196.5 & 3.91 & 7.4 \\
\hline 2003 & 207.9 & 5.80 & 11.4 \\
\hline 2004 & 218.4 & 5.05 & 1.3 \\
\hline 2005 & 219.7 & 0.60 & 12.4 \\
\hline 2006 & 232.1 & 5.64 & 7.6 \\
\hline 2007 & 239.7 & 3.27 & -0.8 \\
\hline 2008 & 238.9 & -0.33 & -10.3 \\
\hline 2009 & 228.6 & -4.31 & -12.5 \\
\hline 2010 & 216.1 & -5.47 & -21.9 \\
\hline 2011 & 194.2 & -10.13 & -13.8 \\
\hline 2012 & 180.4 & -7.11 & -4.5 \\
\hline 2013 & 175.9 & -2.49 & 0.8 \\
\hline 2014 & 176.7 & 0.45 & -0.3 \\
\hline 2015 & 176.4 & -0.17 & -0.9 \\
\hline 2016 & 175.5 & -0.51 & 1.9 \\
\hline 2017 & 177.4 & 1.08 & 3 \\
\hline 2018 & 180.4 & 1.69 & 3.2 \\
\hline 2019 & 183.6 & 1.77 & -16.5 \\
\hline 2020 & 167.1 & -8.99 & 11.8 \\
\hline 2021 & 178.9 & 7.06 & 9.2 \\
\hline 2022 & 188.1 & 5.14 & 6.7 \\
\hline 2023 & 194.8 & 3.56 & \\
\hline
\end{tabular}

Source: Eurostat (AMECO database) and author's calculations.

After 2008, the Greek GDP records huge declines in growth rates, first because of the Great Recession (2008-2016), and recently (2020) because of the pandemic. According to the European Commission's estimates, the 2021-2023 years are expected to show strong economic growth. However, it should be noted that in 2020 the loss of output was 16.5 billion euro and a big part of this loss was due to the decline in international tourism receipts. The estimate of 2021 is for 
only a partial recovery of this amount. It is expected that output will increase by $7.06 \%$ which will add 11.8 billion euro to GDP, which is much lower than the loss of the previous year. As a result, the 2021 GDP is lower than the 2019 GDP.

The following two sections look at what extent these changes are due to a decline of tourism receipts in 2020 relative to 2019 and the increase of tourism receipts of 2021 relative to 2020 .

\section{The International Tourism Receipts of 2020}

The first year of the pandemic was the worst - not so much for its effect in the loss of human lives but because of the uncertainty it created and the unavailability of any vaccine to cope with the virus. Governments reacted under a tremendous pressure, unsure of their policy intervention. ${ }^{1}$ Greece reacted relatively quickly, and by the second quarter of 2020 the Greek borders were locked and all hotels were shut down. They reopened again during the third quarter of 2020. This impact is reflected in the tourism receipts. Table 2 reports the international Greek tourism receipts by quarter and compares them with the three scenarios made and explained in Papanikos (2020a, Table 2, p. 94). The last column reports data of total receipts for the entire year.

Table 2. The Actual Tourism Impact and the Three Scenarios Measured in millions of current euros

\begin{tabular}{|l|c|c|c|c|c|c|}
\hline Row & Quarter & I & II & III & IV & Total \\
\hline 1 & Actual Receipts 2019 & 746.5 & $4,667.2$ & $10,693.4$ & $2,071.7$ & $18,178.8$ \\
\hline 2 & Actual Receipts 2020 & 593.3 & $140.4 *$ & $2,926.4$ & 658.7 & $4,318.8$ \\
\hline 3 & Percentage 2020/2019 & $79.48 \%$ & $3.01 \%$ & $27.37 \%$ & $31.79 \%$ & $23.76 \%$ \\
\hline 4 & Scenario A (worst-case) & 709 & 467 & 1,069 & 207 & $2,452.0$ \\
\hline 5 & Scenario B (average) & 709 & 1,167 & 2,673 & 518 & $5,067.0$ \\
\hline 6 & Scenario C (optimistic) & 709 & 1,867 & 4,277 & 829 & $7,682.0$ \\
\hline 7 & Scenario A Difference & -115.7 & -326.6 & $1,857.4$ & 451.7 & $1,866.8$ \\
\hline 8 & Scenario B Difference & -115.7 & -1026.6 & 253.4 & 140.7 & -748.2 \\
\hline 9 & Scenario C Difference & -115.7 & -1726.6 & -1350.6 & -170.3 & -3363.2 \\
\hline
\end{tabular}

*Based on estimates of Bank of Greece and on the Survey which was not conducted due to the complete lockdown of the tourism sector.

Source: Bank of Greece and author's calculations.

\section{International Tourism Receipts of 2020 and 2019 Compared}

Assuming a normal non-pandemic international tourism environment, the Greek tourism receipts would have been as good as the receipts of 2019, if not higher, based on some anecdotal evidence of prebooking arrangements early on in 2020 and compared with those from 2019. Table 2 measures the impact in terms of the percentage of 2020 tourism receipts to corresponding figures for 2019 , as reported in the third row of the table.

\footnotetext{
${ }^{1}$ Unlike with the negative shock of the Great Recession, the European Union reacted relatively fast in announcing a massive recovery fund of 750 billion euro. I have evaluated this recovery plan in Papanikos (2021).
} 
All quarters of 2020 realised lower international tourism receipts relative to 2019. In total, the tourism receipts of 2020 were only one-fourth $(23.76 \%)$ of the 2019 receipts. However, there are huge variations among the four quarters of the year. The first quarter of 2020 was not affected as much as the other three quarters. Nevertheless, the receipts of the first quarter of 2020 were $79.48 \%$ of the 2019 receipts. The economy was still unaffected by the COVID-19 impact. It was by mid-March that the first measures were taken and spread the fear among the international tourists resulting in immediate cancellations not only for the entire year, but for the remaining few days of the first quarter of the year. The end-ofquarter impact might explain the relatively lower effect. Unfortunately, this has not been the case of the second quarter of 2020. The complete lockdown of the tourism economy has had a devastating effect on international Greek tourism receipts which accounted for only a mere $3.01 \%$ of the corresponding receipts of 2019. Historically, and due to the intense seasonality of Greek tourism, the second quarter of the year brings the second largest international tourism revenue. In 2019, the second quarter accounted for $25.67 \%$ (not shown in Table 2) of total tourism receipts, which is second to the $58.82 \%$ of the third quarter. By the third quarter, there was a partial opening of the tourism economy, but this did not have the positive effect that was expected by the Greek tourism authorities. The international tourism revenues of the third quarter of 2020 were only $27.37 \%$ of the receipts of the third quarter of 2019; similar was the performance of the last quarter of 2020 relative to the fourth quarter of 2019. The tourism receipts were only $31.79 \%$ of the tourism receipts from 2019.

\section{An Ex-Post Evaluation of the Three Forecasting Scenarios}

Papanikos (2020a) gave three scenarios of the possible impacts to tourism in 2020 from COVID-19. The impact of these three scenarios was measured in millions of euros in tourism receipts and is reproduced here in Table 2 (rows 4-6). I had assumed that the first quarter would be only mildly affected and would have resulted in a decrease of about 5\% of the corresponding 2019 receipts under all three possible scenarios. After all, the first two months of the year were unaffected by the pandemic. By mid-March, some measures were taken. The actual decrease was higher than the one forecasted, which resulted in 593.3 million euro of international tourism receipts instead of the 709 million which were expected according to all three possible scenarios. The loss was 115.7 million euro or $15.5 \%$, three times higher than the 5\% suggested by the three-scenario analysis.

At the time of writing the Papanikos (2020a) paper, the possibility of a complete lockdown of the international and national Greek tourism sector was not part of the scenario. Nevertheless, the worst-case scenario asserted that in all quarters of 2020 the total international tourism receipts will account for only $10 \%$ of the 2019 receipts. Even this worst-case scenario underestimated the actual impact. According to this worst-case scenario, the second quarter of 2020 would have resulted in a revenue of 467 million euro instead of the actual revenue of 4,667.2 million euro in the second quarter of 2019. The actual tourism receipts were only 140.4 million euro. It should be noted that the Bank of Greece, which is 
the official authority to collect such data using a survey at the Greek boarders, did not do the survey and provided its own ad hoc estimates for the second quarter. Thus, the analysis of underestimation may not be reliable. The other two scenarios gave much worse predictions for the second quarter of 2020. The average or most probable scenario was predicted revenues of 1,167 million euro, a difference of 1,026.6 million of the actual one. The more optimistic third scenario overpredicted the tourism receipts of the second quarter by $1,726.6$ million euro.

By the third quarter, the Greek tourism economy was partially opened. The three-scenarios analysis expected a tourism revenue of 1,069, 2,673 and 4,277 million euro. The actual tourism revenue was 2,926.4 million euro, which is very close to average or the most probable second scenario, which underpredicted the actual by 253.4 million euro. The worst-case scenario underpredicted the actual tourism receipts by $1,857.4$ million euro and the optimistic scenario over-predicted by $1,350.6$ million euro.

Similar with the third quarter are the results of the estimates for the fourth quarter. The second, most probable or average scenario, under-predicted the actual receipts by 140.7 million euro. The other two scenario under-predicted (first scenario) by 451.7 million euro and over-predicted (third scenario) by 170.3 million euro the actual receipts.

For the entire year, the three-scenarios estimated that the international Greek tourism receipts of 2020 would be 2,452 million euro (worst-case), 5,067 million euro (average or most probable) and 7,682 million euro (optimistic). The actual tourism receipts reported by the Bank of Greece was 4,318.8 million euro. The difference between the actual and the estimated by the three scenarios were +1866.8 (worst-case scenario), -748.2 (average or most probable scenario) and finally -3363.2 (optimistic scenario). In percentage terms, the average or the most probable scenario gave an over-prediction of $17 \%$ of the actual international tourism receipts. This was primarily due to the complete lock down of the Greek tourism market during the second quarter of 2020.

\section{The Tourism Impact in 2021 and 2020 Using Monthly Data}

This section examines the impact of COVID-19 on Greek tourism using actual monthly data on international tourism arrivals and receipts, using 2019 as a benchmark year. In terms of the COVID-19 effect on the number of deaths, in Greece, as in many other countries, the year 2021 was much worse than 2020. In 2020, 4,788 people died from the virus in Greece. In 2021, there were 15,920 deaths. Despite this worsening of the situation, the measures in 2021 were not as restrictive as in the previous year. There are two aspects to that. Firstly, government measures in 2020 were harsher than in 2021. Secondly, people were not as protective in 2021 as they were in 2020. Even the enforcement of measures was not as intense in 2021 as they were in 2020 . This may only partially explain the huge difference in the number of deaths between 2021 and 2020. However, the examination of this serious issue goes beyond the scope of this study. I just mention this because many national and international tourists decided to travel 
around Greece despite the fact that the indicators on COVID-19 were deteriorating. This applied particularly to young people. Also, those who were fully vaccinated felt safe to travel because it was assumed that being infected by the virus was not posing a threat on their life. For all those reasons, Greek tourism in 2021 was expected to recuperate from its dismal performance in 2020.

Table 3 shows that this was exactly the case. The table reports monthly data of the 2019-2021 years of international tourism receipts and tourism arrivals. The last two columns show the international tourist arrivals of 2020 and 2021 as a percentage of 2019 arrivals respectively. The data are also depicted in a graphical form in Figures 2-4.

Table 3. Tourism Receipts and Tourist Arrivals by Month, 2019-2021

\begin{tabular}{|l|c|c|c|c|c|c|c|c|}
\hline & \multicolumn{2}{c|}{$\begin{array}{c}\text { Tourism Receipts } \\
\text { (Million's euro) }\end{array}$} & \multicolumn{3}{c|}{$\begin{array}{c}\text { Tourist Arrivals } \\
\text { (000s) }\end{array}$} & \multicolumn{2}{c|}{ Parentage Changes } \\
\hline Month & $\mathbf{2 0 1 9}$ & $\mathbf{2 0 2 0}$ & $\mathbf{2 0 2 1}$ & $\mathbf{2 0 1 9}$ & $\mathbf{2 0 2 0}$ & $\mathbf{2 0 2 1}$ & $\mathbf{2 0 2 0 / 2 0 1 9}$ & $\mathbf{2 0 2 1 / 2 0 1 9}$ \\
\hline 1 & 230 & 281 & 34 & 660 & 790 & 96 & $120 \%$ & $15 \%$ \\
\hline 2 & 198 & 221 & 33 & 504 & 627 & 76 & $125 \%$ & $15 \%$ \\
\hline 3 & 318 & 92 & 39 & 773 & 411 & 99 & $53 \%$ & $13 \%$ \\
\hline 4 & 543 & 14 & 59 & 982 & 38 & 107 & $4 \%$ & $11 \%$ \\
\hline 5 & 1566 & 44 & 222 & 2387 & 56 & 285 & $2 \%$ & $12 \%$ \\
\hline 6 & 2558 & 83 & 807 & 4102 & 256 & 1069 & $6 \%$ & $26 \%$ \\
\hline 7 & 3703 & 678 & 2288 & 5673 & 828 & 2817 & $15 \%$ & $50 \%$ \\
\hline 8 & 4104 & 1381 & 3156 & 6762 & 1807 & 4074 & $27 \%$ & $60 \%$ \\
\hline 9 & 2886 & 868 & 2113 & 5111 & 1335 & 2995 & $26 \%$ & $59 \%$ \\
\hline 10 & 1462 & 554 & 1438 & 2773 & 955 & 2144 & $34 \%$ & $77 \%$ \\
\hline 11 & 315 & 70 & 287 & 930 & 176 & 561 & $19 \%$ & $60 \%$ \\
\hline 12 & 294 & 35 & 177 & 692 & 97 & 380 & $14 \%$ & $55 \%$ \\
\hline Total & 18179 & 4319 & 10653 & 31348 & 7374 & 14705 & $24 \%$ & $47 \%$ \\
\hline$\%$ of 2019 & $100 \%$ & $24 \%$ & $59 \%$ & $100 \%$ & $24 \%$ & $47 \%$ & & \\
\hline
\end{tabular}

A number of observations can be made based on Table 3 and the 3 graphs below. First, in 2020 tourism receipts accounted for $24 \%$ of the corresponding receipts of 2019, which is used as the reference year. Tourist arrivals also accounted for only $24 \%$. However, this is not the real cost of the pandemic, i.e., to compare it with the 2019, even though it was a record year for Greek tourism. The real cost can be found if we were able to compare the actual tourism data with what would have been if there was no pandemic. Most probably the tourism receipts and tourist arrivals would have been much higher in 2020 than in 2019. Figure 2 shows the percentages by month. The first two months of 2020 were unaffected by the pandemic. Tourist arrivals in January and February of 2020 were $120 \%$ and $125 \%$ of the tourist arrivals of the corresponding months of 2019. Higher were also the international tourism receipts in the first two months of 2020 relative to 2019 (not shown in the graphs).

Figure 2 shows that 2021 was a much better year than 2020 despite, as mentioned above, the much worse numbers of deaths due to COVID-19. The second half of 2021 accounted for more than $50 \%$ of tourist arrivals in 2019 . The month of October 2021 did exceptionally well with $77 \%$ of the 2019 tourist arrivals. It looks like there is an upward trend, which many tourism experts expect to continue into 2022. 
Figure 2. The Percentage of Tourist Arrivals in 2020 and 2021 Relative to 2019

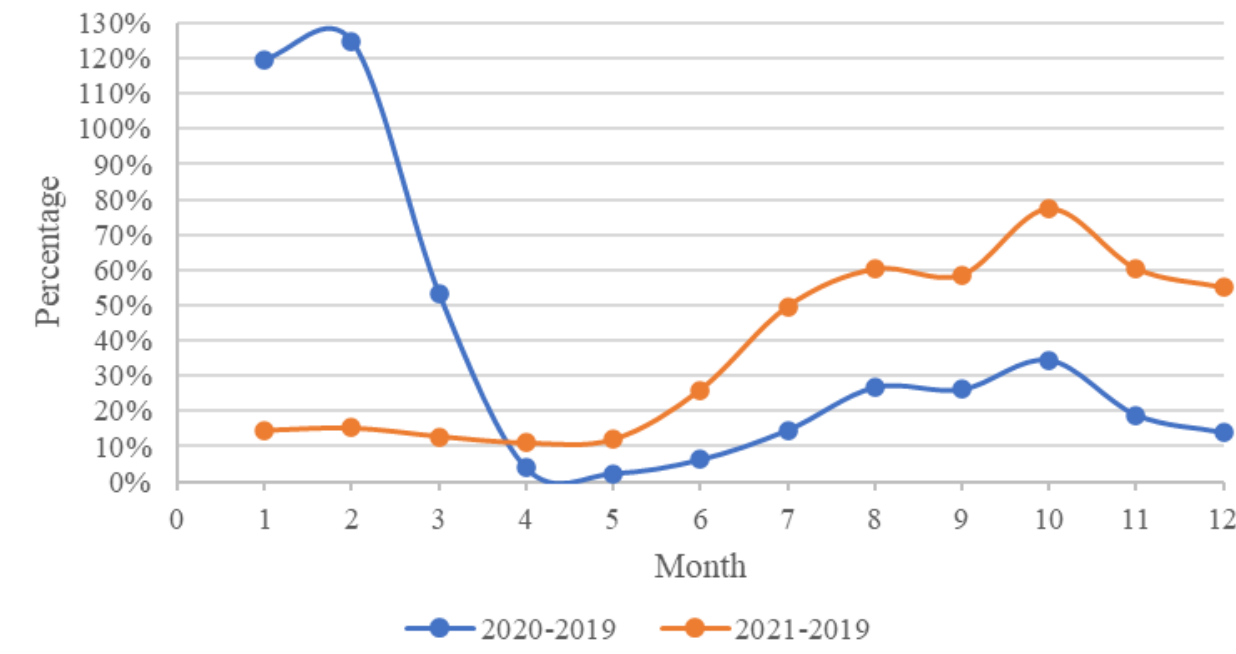

Figure 3. Tourism Receipts (in millions of euros)

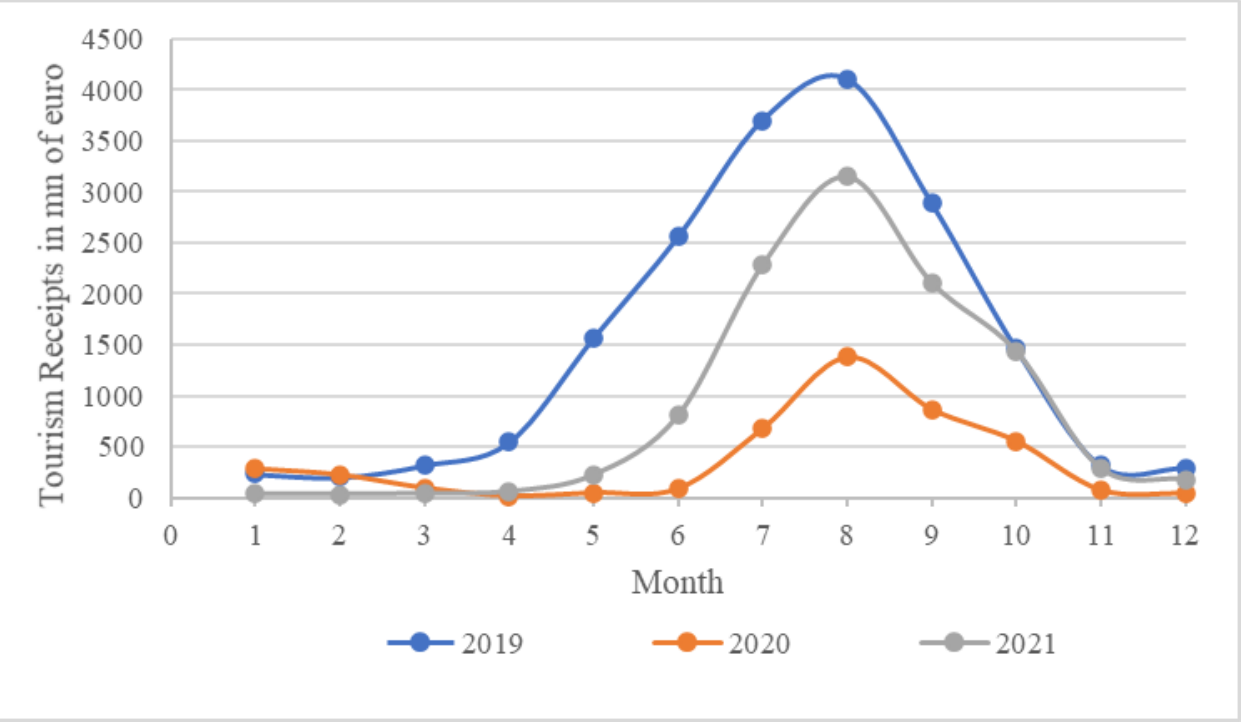

Figures 3 and 4 show, once again, one of the biggest problems of the Greek tourism industry is its seasonality, which despite COVID-19, still appears in the two graphs. The month of August records higher tourism receipts and tourism arrivals. July and September were on equal footing in the two pandemic years, but in 2019 as well as in all previous normal years (not shown in the graphs) the month of July is much better than the month of September. 
Figure 4. Tourism Arrivals (in 000s)

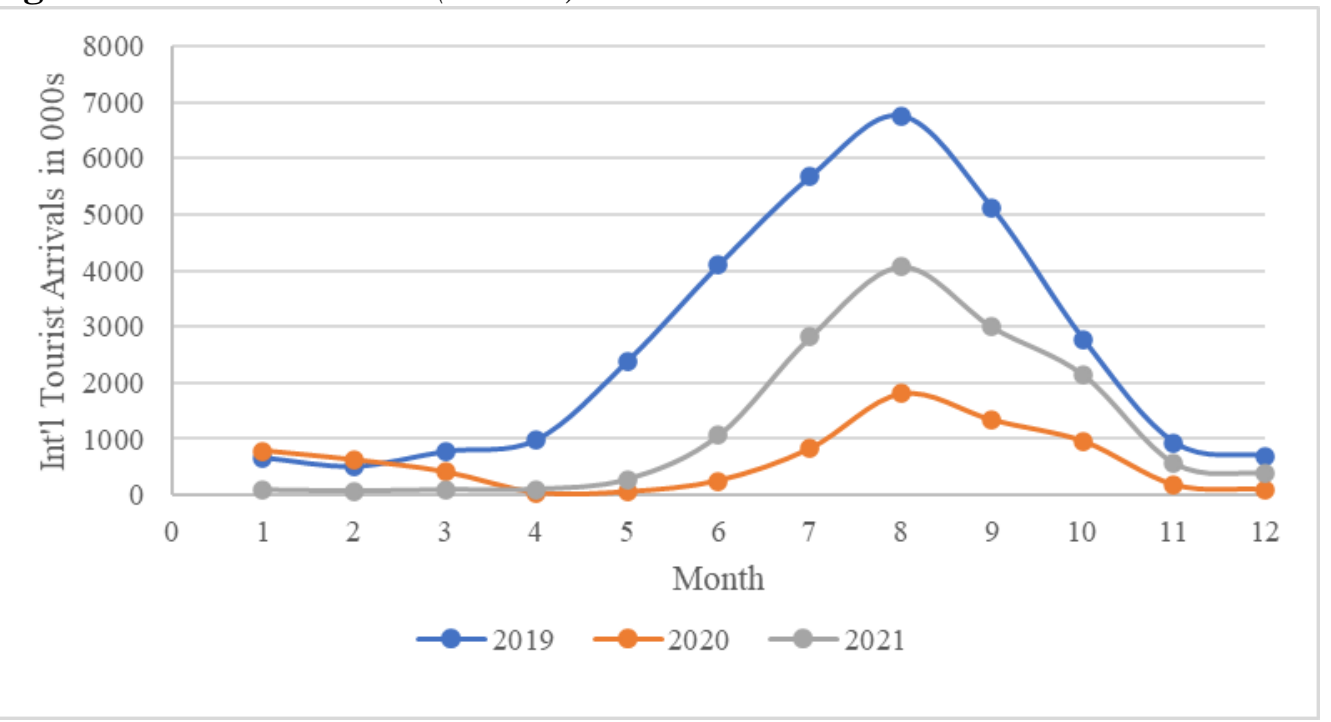

\section{Conclusions}

This study updated Papanikos' (2020a) study which provided some estimates of the economic and tourism impacts of COVID-19. The study here updated and compared those findings. The actual tourism data of 2020 confirm that the average or most probable scenario of the COVID-19 impact did provide the closest predictions. However, there was a $17 \%$ over-prediction of the actual international tourism receipts primarily because at the time of the forecast, the complete lock down of the tourism sector could not have been foreseen.

The second conclusion which emerges from examining the 2020 and 2021 data on international tourism receipts and tourist arrivals is that 2021 was a much better year than 2020 despite that the number of deaths was much higher in 2021 relative to 2020. This shows that if the situation with the pandemic does not deteriorate, the Greek tourism will fully recover in 2022 and may quite possibly reach the same receipts and arrivals as in 2019.

\section{References}

Boutsioli Z, Bigelow V, Gkounta O (2022) Essays on COVID-19. Ahens: Athens Institute for Education and Research (ATINER).

Jones P, Comfort D (2020) The COVID-19 crisis, tourism and sustainable development. Athens Journal of Tourism 7(2): 75-86.

Papanikos GT (1999) Tourism impact of the 2004 Olympic Games. Athens: Tourism Research Institute. (In Greek).

Papanikos GT (2000) The Greek small and medium sized hotel enterprises. Athens: Research Institute of Tourism. (In Greek).

Papanikos GT (2001) Regional analysis of Greek hotels. Athens: Research Institute of Tourism. (In Greek). 
Papanikos GT (2002) Employment in the accommodation sector. Athens: Research Institute of Tourism. (In Greek).

Papanikos GT (2005) The Greek tourist receipts. Athens: Research Institute of Tourism. (In Greek).

Papanikos GT (2014) The Greek economic crisis: a class analysis in favor of the memorandum. Athens: Athens Institute for Education and Research (ATINER). (In Greek).

Papanikos GT (2015) The real exchange rate of euro and Greek economic growth. The Journal of Economic Asymmetries 12 (Nov): 100-109.

Papanikos GT (2020a) The impact of the COVID-19 pandemic on Greek tourism. Athens Journal of Tourism 7(2): 87-100.

Papanikos GT (2020b) Thucydides and the synchronous pandemic. Athens Journal of History 7(1): 71-94.

Papanikos GT (2021) The European Union's recovery plan: a critical evaluation. Athens Journal of Mediterranean Studies 7(2): 85-102.

Papanikos GT (2022a) Greece in the Eurozone: an evaluation of the first two decades. Athens Journal of Business \& Economics 8(2): 177-192.

Papanikos GT (2022b) An ex-post analysis of the 2004 Olympic effect. Athens Journal of Sports 9(1): 51-58. 
